\title{
Assessment of apple varieties based on consumer judgement on their fruits of organic production for fresh consumption
}

\author{
Felföldi, J. ${ }^{1}$, Szabó, T. ${ }^{2}$, Nyéki, J, ${ }^{3}$, Soltész, M. ${ }^{2}$, Szabó, Z. ${ }^{3}$ \& Apáti, F. ${ }^{1}$ \\ ${ }^{1}$ Department of Agrobusiness Management, Faculty of Applied Economics and Rural Development, \\ CASE, University of Debrecen \\ ${ }^{2}$ Ujfehértói GYKSZNK Ltd. \\ ${ }^{3}$ Research and Development Institute, CASE, University of Debrecen
}

\begin{abstract}
Summary: The lack of information is often cause of the insufficiency of attributes being developed and appears on the new commodity characterising its utility. Neither own nor other information is presented. For improving this handicap, we endeavoured to praise apple products grown by biological methods and explain their properties as taste, skin, colour, consistency, and size. In addition, we explore the relation between general impression and the individual properties. The scrutiny starts with collecting of primary data on 9 samples taken from biologically grown apple varieties kept over 60-90 days in a store and offered to the consumers. The test is based on an organoleptic assessment (records are registered in a questionnary). The individual judgements are processed and coefficients of correlation between the traits (taste, skin, size, colour) calculated. The validity of the mathematically proved relations is considered to be decisive judging the preferences in consumption of fruits.
\end{abstract}

Key words: organic, apple variety, fresh product, attributes, correlation, consumer

\section{Introduction}

The development of a new commodity requires an adequate presentation of its attributes in order to distinguish its identity regarding its inner as well as outer appearance. A secondary source of data is still not available, therefore we prefer to raise information by inquiry. Primary information is collected from researchers or growers and utilised as a guide for their professional activity.

Primary research is applied preferably in marketing and in social sciences and it's a dominant way of empirical enquiries. First attempts started at the beginning of the $20^{\text {th }}$ century. For this purpose, a questioner or interrogator, actually both are used as expedients. On the Hungarian apple market Felföldi et al. (2008) published already a survey. Further results on attitudes of consumers are available as Vanczák et al. (2002) and Gonda et al. (2007), representing earlier periods. Data on vegetable and fruit consumption, its frequency and the consumer's conscience is treated in TNS (2009). Interrogations may yield information, which is but hardly available by other means (Hoffmann et al., 2001).

Our purpose is to raise primary data in favour of stimulating the consumption of fresh apple fruit. The targets set are the following:

Apple products grown by biological methods should be evaluated according to their taste, skin, colour, consistency and size.
On the samples examined the relation between the individual parameters and the general impression is calculated.

\section{Materials and methods}

The survey has been realised in 2008-2009 by means of "interrogators". The evaluation according to individual properties was performed by 110 subjects and compared. This was a raising of primary data on 9 apple varieties grown by biological growing system. The tests were conducted applying the usual way. Results of the organoleptic test are marked in the questionnaire. The main questions, why the apple was desirable and what was the weight of individual properties in winning ones sympathy including also outer characters as colour and size of the fruit. Inner characters are of course the main objectives: taste, skin and consistency of the flesh.

The evaluation has been concentrated, as expressed on the questionnaire, on the five characters: taste, skin, colour, consistency and size. Every character has been rated on a scale of five grades (1-5) in each sample, moreover, the same scale was applied to characterise the general impression of the respective sample. The tests were repeated four times at different localities. The samples and facilities have been provided by the Institute of Újfehértó. In order to avoid 
boring effects, the term of a test lasted 2-3 hours for the 9 apple varieties altogether.

For the purpose to reveal similarities and intrinsic relations between the individual properties, algorithms of correlation have been applied as well as non-parametric tests. For the coefficients of correlation, the Kendall-tau-b tests were used.

\section{Results}

\section{Results of the tests obtained on apple samples}

Results of tests performed on apple samples grown by biological system are shown in Figures 1-5. The row of the 9 varieties follows always the same order. In Figure 1, the colour of the samples is presented. Preferences of the colour are expressed on the scale. Most favourable was the variety Florina, but the next four varieties (Rajka, Topáz, and Rubinola) are almost as good.

We remark that the colour of apples are judged to be red or light red as being asked from the subjects.

Red varieties were preferred to the light red ones. In case of Florina, however, the red colour was combined with greenish-red, which $1 / 3$ of the subjects judged as green and $2 / 3$ of them as red. The light red fruits were less attractive. Not only the colour but also the size of the fruits was advantageous in Topáz, Rajka and Florina, the diameter of the fruits being $70-75 \mathrm{~mm}$. Rubinola was judged to be variable, $78-80 \mathrm{~mm}$, so Príma was preferred with $76 \mathrm{~mm}$. The rest of varieties were criticised for its heterogeneity, less favoured were Resi, Rewena and Releika. Fruits of Rewena had $69 \mathrm{~mm}$ diameter, which was found in other, more liked varieties, but Rewena was too heterogeneous. Resi and Releika fruits were also small and variable. Figure 2 shows the distribution of size according to varieties..

Figure 3 - Results of the evaluation of fruit taste according to varieties grown with biological technology. Topáz was the best, Rajka the next, Rubinola and Florina were less tasty but th most rejected

Source: original data

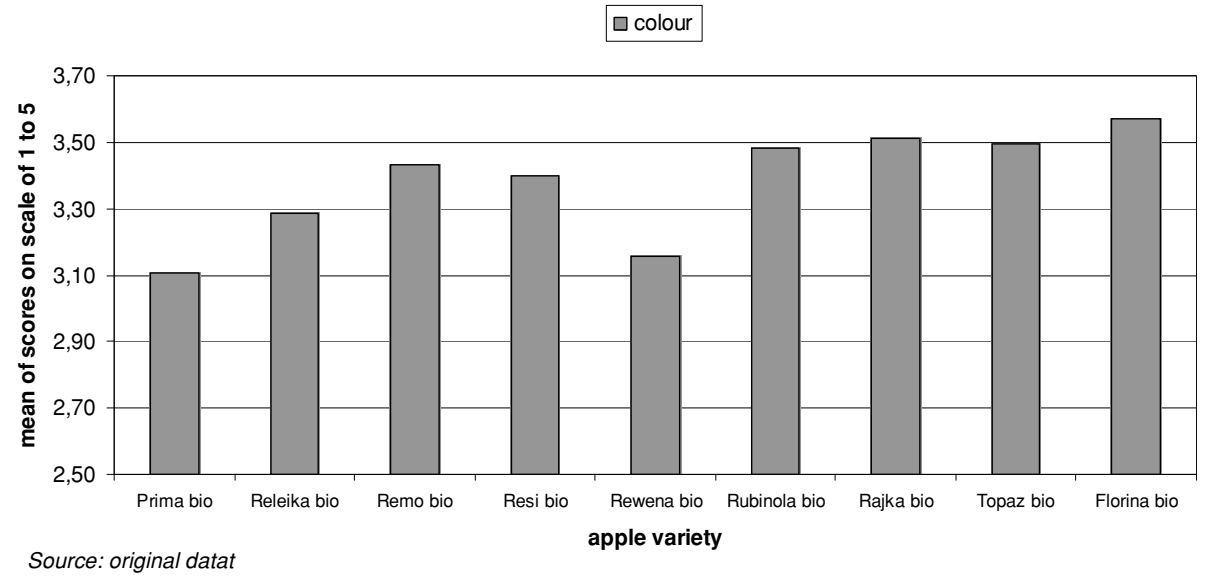

Figure 1: Mean ratings of varieties according to their colour

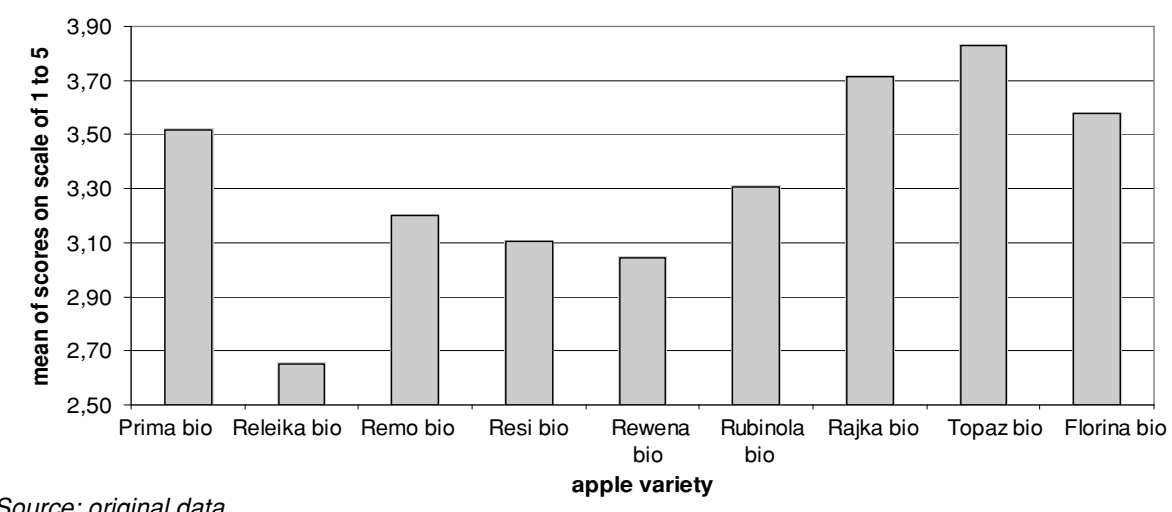

Figure 2: Size scores of fruits according to varieties

were Rewena and Remo. The taste depended most on sugar and acid content of fruits. Sugar content was expressed by the Brix-degrees, acidity by the equivalent citric acid content. Topáz produced 12.4 Brix $^{\circ}$ and $4.9 \mathrm{~g} / \mathrm{kg}$ acidity; Rajka 13.6 Brix $^{\circ}, 2.6 \mathrm{~g} / \mathrm{kg}$ acidity. The next were Resi with 12,2 Brix $^{\circ}$ slightly acid $(2.8 \mathrm{~g} / \mathrm{kg})$, followed by Rubinola with $13 \mathrm{Brix}^{\circ}$ and $3.8 \mathrm{~g} / \mathrm{kg}$, further on, Rewena $12.4 \mathrm{Brix}^{\circ}$ and $5.2 \mathrm{~g} / \mathrm{kg}$ acidity, Remo $13.3 \mathrm{Brix}^{\circ}$ and $5.3 \mathrm{~g} / \mathrm{kg}$ acidity. We stated that

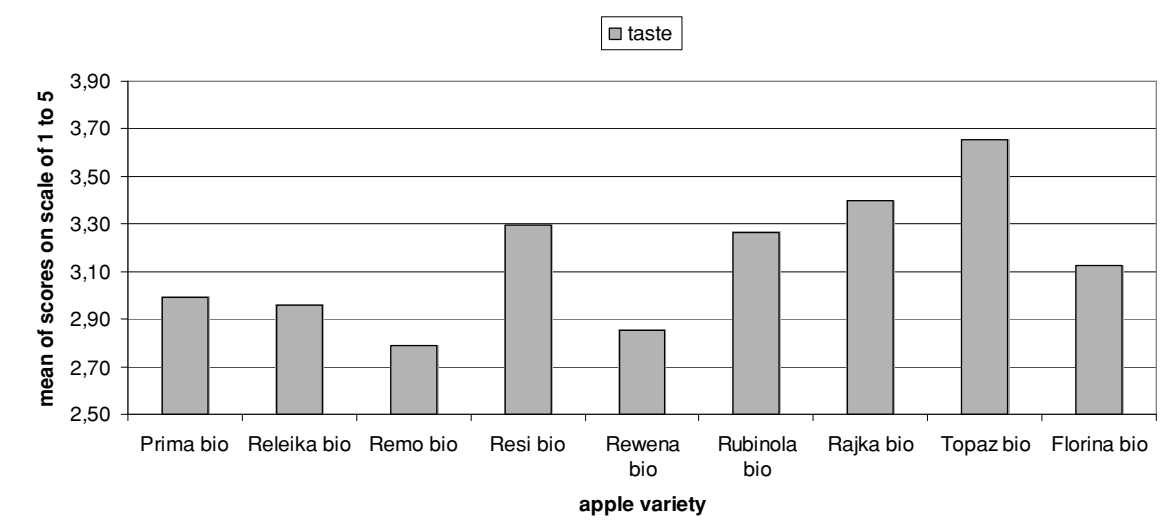

Figure 3: Mean scores given to taste for the nine varieties examined 
sweet and less acid varieties are preferred. Taste is dependent on the combination of sugars and acids, i.e. their harmony. The preferred rate is a matter of further research.

The consistency (firmness) of the fruit flesh did not differ markedly, but Resi and Topaz were somewhat better than the rest. (Figure 4).

Resi 3.62, and Topáz 3.53 received the best rates. The other varieties had lower values around 3.0. The skin was best in Resi with 3.33 average followed by Topáz, Rajka, and Rubinola with scores around 3.2. No substantial differences have been found, but four of them seem to be better than the rest. The lowest value was 2.96 in the variety Prima (Figure 5).

After having combined the five scores (Figure 6), the winner variety was Topáz, but Rajka and Resi were better than the rest. We may distinguish three groups of varieties regarding the consumers' preference. The best grades are given to Topaz, Rajka, Resi, the intermediate group: Rubinola, Florina, and the less desirables: Remo, Príma, Rewena and Releika.

\section{The relation between the individual characters and the general impression}

Participants of the tests were asked to rate their general impression after having done it with the five characters separately on the same scale of 5 degrees. The question should be answered, which is the relation between the individual scores and the general impression. This should be expressed by the coefficients of correlation. (Table 1).

Data shown in Table 1 prove a significant correlation between all the five individual characters with the general impression. Comparison by pairs by the Kendall-tau-b test gave significant values. Taking the diminishing order of their value, the range of coefficients between individual characters and general impression was: taste, consistency, skin, size, colour. We can state that the taste is most decisive: 0.67 , next the consistency: 0.612 , the skin: 0.563 , the size: 0.491 , and the colour: 0.475 . It is evident that all those individual characters are significantly influencing the choice of the consumers. This justifies the use those $\square$ consistency of flesh

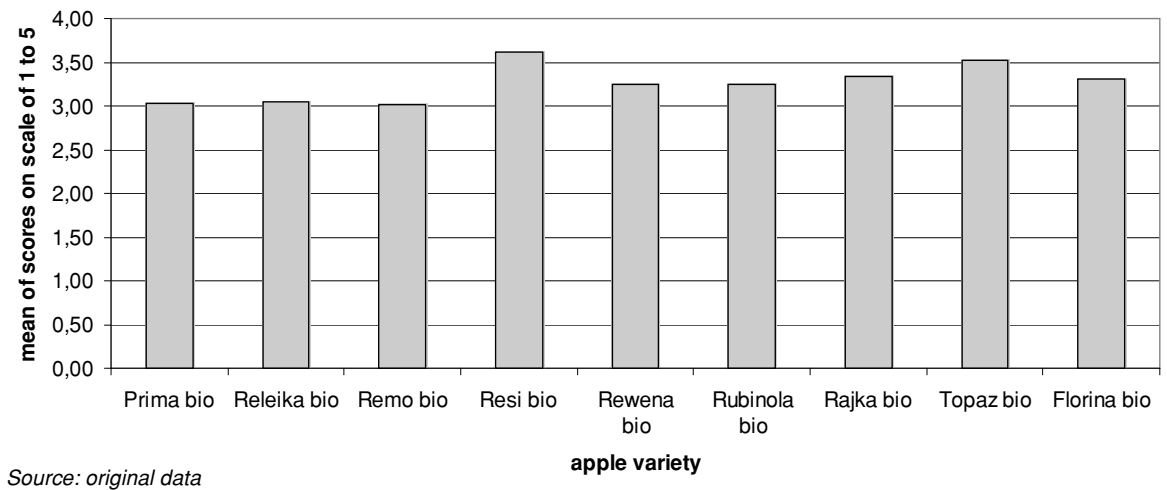

Figure 4: Mean scores given to the consistency of fruit flesh of the varieties.

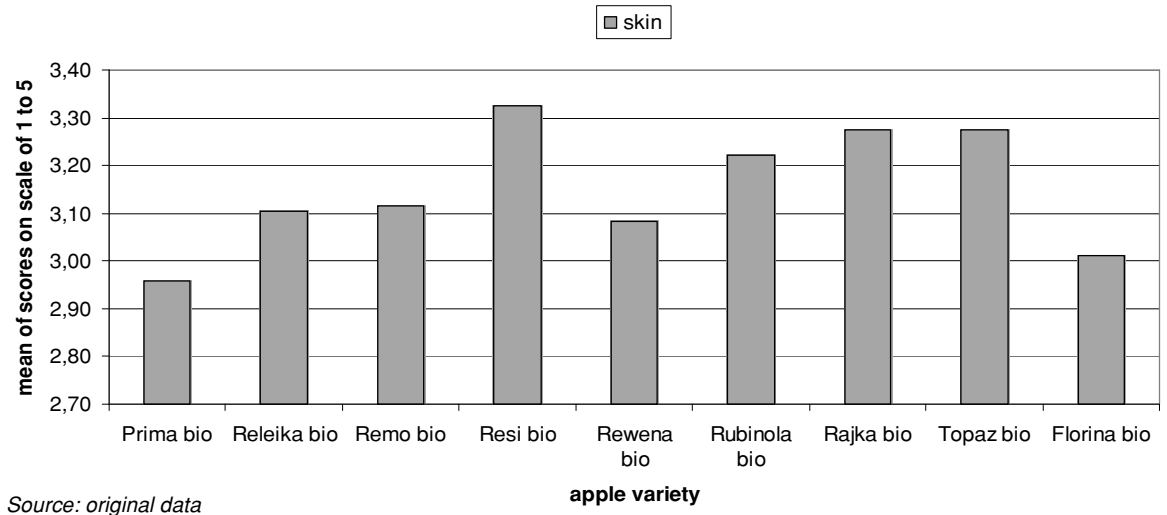

Figure 5: Mean scores given to the quality of skin

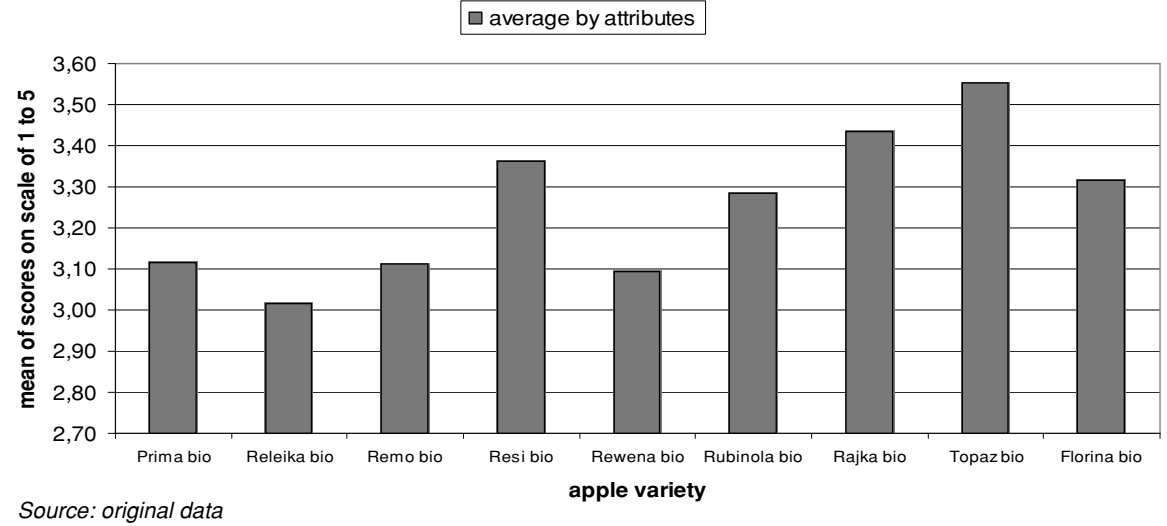

Figure 6: Mean values of the scores of five attributes combined

characters to identify consumers' preferences in the choice of varieties.

\section{Conclusions}

Participants of the consumers' tests generally like the red colour, though light red is less popular for them. In spite of that, the association of red colour with green was also advantageous. The colour and the size of the fruit together 
Table 1. Relation between the scores of individual characters and of general impression

\begin{tabular}{|c|c|c|c|c|c|c|c|}
\hline & Kendall's tau_b & Colour & Size & Taste & Consistency & Skin & $\begin{array}{c}\text { General } \\
\text { impression }\end{array}$ \\
\hline \multirow[t]{3}{*}{ Colour } & Correlation Coefficient & 1 & $0.457(* *)$ & $0.282(* *)$ & $0.322(* *)$ & $0.341(* *)$ & $0.475(* *)$ \\
\hline & Sig. (2-tailed) & . & 0 & 0 & 0 & 0 & 0 \\
\hline & $\mathrm{N}$ & 915 & 915 & 915 & 915 & 915 & 915 \\
\hline \multirow[t]{3}{*}{ Size } & Correlation Coefficient & $0.457(* *)$ & 1 & $0.302(* *)$ & $0.292(* *)$ & $0.292(* *)$ & $0.491(* *)$ \\
\hline & Sig. (2-tailed) & 0 & . & 0 & 0 & 0 & 0 \\
\hline & $\mathrm{N}$ & 915 & 916 & 916 & 916 & 916 & 916 \\
\hline \multirow[t]{3}{*}{ Taste } & Correlation Coefficient & $0.282(* *)$ & $0.302(* *)$ & 1 & $0.533(* *)$ & $0.424(* *)$ & $0.670(* *)$ \\
\hline & Sig. (2-tailed) & 0 & 0 & . & 0 & 0 & 0 \\
\hline & $\mathrm{N}$ & 915 & 916 & 916 & 916 & 916 & 916 \\
\hline \multirow[t]{3}{*}{ Consistency } & Correlation Coefficient & $0.322(* *)$ & $0.292(* *)$ & $0.533(* *)$ & 1 & $0.490(* *)$ & $0.612(* *)$ \\
\hline & Sig. (2-tailed) & 0 & 0 & 0 & . & 0 & 0 \\
\hline & $\mathrm{N}$ & 915 & 916 & 916 & 916 & 916 & 916 \\
\hline \multirow[t]{3}{*}{ Skin } & Correlation Coefficient & $0.341(* *)$ & $0.292(* *)$ & $0.424(* *)$ & $0.490(* *)$ & 1 & $0.563(* *)$ \\
\hline & Sig. (2-tailed) & 0 & 0 & 0 & 0 & . & 0 \\
\hline & $\mathrm{N}$ & 915 & 916 & 916 & 916 & 916 & 916 \\
\hline \multirow[t]{3}{*}{ General impression } & Correlation Coefficient & $0.475(* *)$ & $0.491(* *)$ & $0.670(* *)$ & $0.612(* *)$ & $0.563(* *)$ & 1 \\
\hline & Sig. (2-tailed) & 0 & 0 & 0 & 0 & 0 & . \\
\hline & $\mathrm{N}$ & 915 & 916 & 916 & 916 & 916 & 916 \\
\hline
\end{tabular}

**Correlation is significant at the 0.01 level (2-tailed)

was esteemed in the varieties Topáz, Rajka and Florina. The preferred mean size was $70-75 \mathrm{~mm}$ of diameter, but the sample should be homogeneous. The acceptance of size was rather tolerant, also $65 \mathrm{~mm}$ was accepted provided the sample was homogeneous. Taking the taste alone Topaz was the best followed by Rajka. Preferred were the sweet and less acid varieties, but we have to consider that the harmony between the two components is decisive, which should be the matter of further studies.

The consistency of fruit flesh was less variable in the present test, similarly, the fruit skin, though four of them received better scores: Resi, Topáz, Rajka, Rubinola. Regarding all the five characters together, three varieties were outstanding: Topáz, Rajka and Resi. Intermediate were Rubinola and Florina, whereas Remo, Príma, Rewena and Releika lagged behind.

Correlation coefficients between the individual characters and the general impression prove the validity of taking into account the five individual characters being decisive in building up the general impression. Somewhat weaker, but worth while to consider, are the correlations between the characters examined.

\section{Acknowledgments}

This paper was supported by the János Bolyai Research Scholarship of the Hungarian Academy of Sciences.

\section{References}

Felföldi, J., Apáti, F. , Szabó, V. \& Nábrádi, A. (2008): Fogyasztói attitüdök az almapiacon. Élelmiszer, Táplálkozás és Marketing The Hungarian Journal of Food, Nutrition And Marketing 2008/2-3 sz. Kaposvári Egyetem, 87-92. p.

Gonda, I., Dremák, P., Vaszily, B. \& Rakonczás, N. (2007): Marketingprogram kidolgozása a hazai frissalma fogyasztás növelése érdekében, Kutatási jelentés

Hoffmann, M., Veres, Z. \& Kozák, Á. (2001): Piackutatás. Müszaki Kiadó, Budapest 27.p. 41.p. 44.p. 204-209.p.

TNS (2009): Vásárlói tudatosság. Progresszív Magazin. Crier Media Csoport. XVII. évf. 4. szám, 50. p.

Vanczák, E., Takácsné György, K. \& Komáromi, N. (2002): A gyümölcs- és almafogyasztás helyzete, egy kérdőíves felmérés eredményei. Kertgazdaság, 34. (2.): 55-60 pp. 